\title{
Impact of climate variability on tropospheric ozone
}

\author{
Volker Grewe* \\ Institut für Physik der Atmosphäre, DLR-Oberpfaffenhofen, 82234 Wessling, Germany
}

Received 23 February 2006; received in revised form 4 December 2006; accepted 2 January 2007

\begin{abstract}
A simulation with the climate-chemistry model (CCM) E39/C is presented, which covers both the troposphere and stratosphere dynamics and chemistry during the period 1960 to 1999 . Although the CCM, by its nature, is not exactly representing observed day-by-day meteorology, there is an overall model's tendency to correctly reproduce the variability pattern due to an inclusion of realistic external forcings, like observed sea surface temperatures (e.g. El Niño), major volcanic eruption, solar cycle, concentrations of greenhouse gases, and Quasi-Biennial Oscillation. Additionally, climate-chemistry interactions are included, like the impact of ozone, methane, and other species on radiation and dynamics, and the impact of dynamics on emissions (lightning). However, a number of important feedbacks are not yet included (e.g. feedbacks related to biogenic emissions and emissions due to biomass burning). The results show a good representation of the evolution of the stratospheric ozone layer, including the ozone hole, which plays an important role for the simulation of natural variability of tropospheric ozone. Anthropogenic $\mathrm{NO}_{x}$ emissions are included with a step-wise linear trend for each sector, but no interannual variability is included. The application of a number of diagnostics (e.g. marked ozone tracers) allows the separation of the impact of various processes/emissions on tropospheric ozone and shows that the simulated Northern Hemisphere tropospheric ozone budget is not only dominated by nitrogen oxide emissions and other ozone pre-cursors, but also by changes of the stratospheric ozone budget and its flux into the troposphere, which tends to reduce the simulated positive trend in tropospheric ozone due to emissions from industry and traffic during the late 80 s and early 90s. For tropical regions the variability in ozone is dominated by variability in lightning (related to ENSO) and stratospheretroposphere exchange (related to Northern Hemisphere Stratospheric dynamics and solar activity). Since tropospheric background chemistry is regarded only, the results are quantitatively limited with respect to derived trends. However, the main results are regarded to be robust.

Although the horizontal resolution is rather coarse in comparison to regional models, such kind of simulations provide useful and necessary information on the impact of large-scale processes and inter-annual/decadal variations on regional air quality. (C) 2007 Elsevier B.V. All rights reserved.
\end{abstract}

Keywords: Climate change; Global modelling; Air quality; Ozone trends

\section{Introduction}

The chemical composition of the atmosphere shows a large variability on a variety of time scales. Additionally, systematic changes have been measured, which

\footnotetext{
* Tel.: +49 8153282536.

E-mail address: Volker.Grewe@dlr.de.
}

largely can be attributed to anthropogenic activities. As an example, measurements of the stratospheric ozone layer show a clear decline from the 1970 s to 2000 , which is mainly resulting from emissions of chlorofluorocarbons (CFCs) (e.g., WMO (2003)). On the other hand, Northern hemisphere mid-latitude surface stations show an increase of tropospheric ozone by up to $30 \%$ for the same time period (e.g. Oltmans et al., 1998, 2006; 
Logan et al., 1999; Vingarzan, 2004). Many tropospheric urban time series show a slight decrease from the mid80 s onwards, which is not fully understood (Oltmans et al., 2006; Jonson et al., 2006; Monks, 2000). On the other hand, measured background ozone shows an increase during the 90s (Volz-Thomas et al., 2003). E.g. for Mace Head, Ireland, Derwent et al. (2004) reported an increase of $0.5 \mathrm{ppbv}$ per year. Besides these longterm changes, there are clear year to year variations. The main factors, which impact this natural variability, have to be understood in order to be able to interpret measured trends. Based hereon a separation of trends from natural variability will form the basis to attribute ozone changes to human activity.

The stratospheric general circulation is characterized by an uprising in the tropics and downward transport at high latitudes (e.g. Dunkerton, 1978). One stratospheric ozone production region is clearly the tropical midstratosphere, where ozone production and destruction leads to an almost photochemical equilibrium of ozone. However, simulations with the model E39/C clearly indicate that mid- and high latitude lower stratospheric ozone may well be produced at mid- and high latitudes and this may dominate over ozone transport from the tropics (Grewe, 2006). In the troposphere, the ozone concentration is dominated by ozone influx from the stratosphere and by ozone production, basically initiated by the reaction of $\mathrm{HO}_{2}+\mathrm{NO} \rightarrow \mathrm{OH}+\mathrm{NO}_{2}$ (background chemistry), a subsequent photolysis of $\mathrm{NO}_{2}$ and a recombination with oxygen molecules. These processes are subject to temporal variability, e.g. the 11-year sun spot cycle significantly affects the stratospheric ozone production and concentration in the stratosphere, resulting in a tropical total ozone variation induced by the solar cycle of $\pm 2 \%$ (WMO, 2003). Grewe (2006) presented the Northern Hemisphere ozone influx and showed that approximately $35 \%$ of the ozone influx originates from tropical stratospheric ozone on both hemispheres. Therefore, it can be expected that the 11year solar cycle introduces a variability of the ozone influx of approximately $\pm 1 \%(\sim 4 \mathrm{Tg}$ /year $)$.

In the tropical troposphere the $\mathrm{NO}_{x}$ and ozone concentration largely depends on the lightning produced $\mathrm{NO}_{x}$ (e.g. Lelieveld and Dentener, 2000; Grewe, 2004). The El Niño/La Niña phenomenon is the most important natural climate variability in the tropics and affects lightning occurrence and therefore ozone concentration (climate-chemistry interaction). When considering air quality, it is clear that the near surface concentrations are mainly controlled by local and regional emissions. However, those concentrations are also affected by large scale transport, especially in winter (Ordóñez et al., 2005).
In this paper, a climate-chemistry simulation for the troposphere and stratosphere is analysed, which covers the period 1960 to 1999 (Dameris et al., 2005). Special diagnostics are applied in order to separate individual effects. Among the numerous climate-chemistry interactions existing in nature, those, which are regarded to be well enough represented by the model, are analysed. I.e. interactions between stratospheric dynamics and tropospheric ozone budget and the impact of El Niño induced variability on tropospheric chemistry. Section 2 introduces briefly the model and the experimental setup. Section 3 describes the methodologies applied to attribute ozone changes to various atmospheric processes. Section 4 concentrates on stratospheric variability and its impact on the tropospheric ozone influx, whereas the tropospheric variability is analysed in Section 5. A discussion of the results is provided in Section 6 .

\section{Model description and experimental set up}

The applied global climate-chemistry model E39/C (Hein et al., 2001) consists of the troposphere-stratosphere climate model ECHAM4.L39(DLR) (Land et al., 1999) coupled to the troposphere-stratosphere chemistry module CHEM (Steil et al., 1998). The climate model is a derivate of the standard ECHAM4 model (Roeckner et al., 1996), with a higher vertical resolution especially at tropopause levels $(\sim 700 \mathrm{~m})$ to better represent processes and gradients in this region. CHEM includes homogeneous and heterogeneous stratospheric reactions, as well as the tropospheric background chemistry $\mathrm{CH}_{4}-\mathrm{CO}-$ $\mathrm{NO}_{x}-\mathrm{HO}_{x}-\mathrm{O}_{3}$. However, NMHC chemistry is not included. A total of 37 species and 107 reactions are applied. A speciality of the model is the amount of allowed interactions, e.g. the hydrological cycle is directly coupled to the chemistry scheme, photolysis scheme, wet deposition and lightning. Changes in the composition of radiatively active species directly affect dynamics via the radiation scheme. The model system has been intensively validated against measurements including a variety of international validation activities (Brunner et al., 2003, 2005; Austin et al., 2003; Shine et al., 2003) and has been applied for a variety of scientific questions with regard to the future development of the ozone layer (Schnadt et al., 2002; Dameris et al., 2006), aircraft impacts (Grewe et al., 2002a; and references therein), etc.

In this paper a simulation from 1960 to 1999 is analysed, which is fully described in Dameris et al. (2005). It includes a variety of changing boundary conditions: Monthly mean observed sea surface temperatures are employed (Rayner et al., 2003); The 11- 

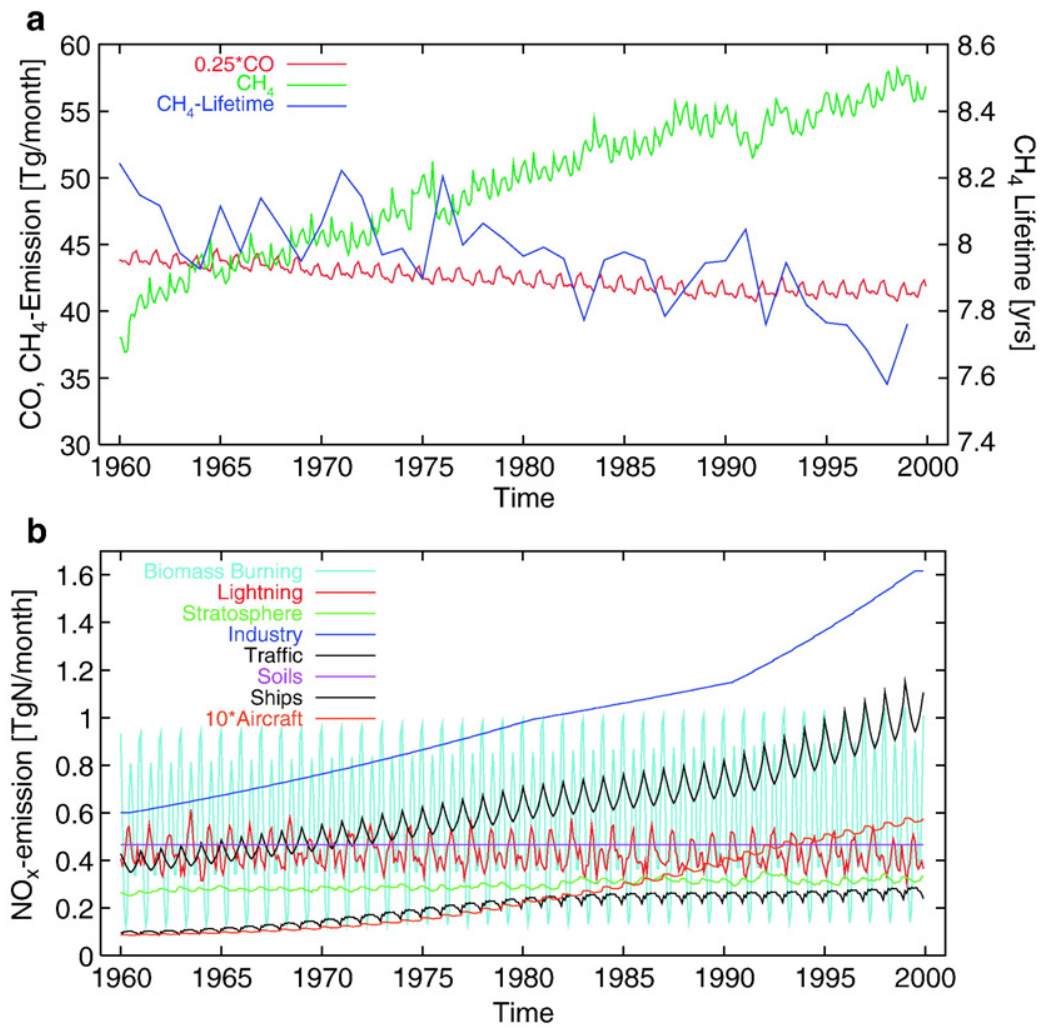

Fig. 1. a) Temporal evolution of implicit simulated methane (green) and carbon monoxide (red) emissions [Tg/month] and methane lifetime [years]. $\mathrm{CO}$ emissions are scale down by a factor of 4 (for plotting only) to fit the same scale. b) $\mathrm{NO}_{x}$ emissions as prescribed or implicitly calculated (lightning, stratosphere) [TgN/year]. (For interpretation of the references to colour in this figure legend, the reader is referred to the web version of this article.)

year solar cycle is included by a parameterisation of the extra-terrestrial flux of 8 spectral wave lengths based on variations of the observed $10.7 \mathrm{~cm}$ radiation flux of the sun and variations of the solar constant to account for variations of the short-wave heating rates. The QuasiBiennial-Oscillation (QBO) is implemented by linear relaxation of the predicted zonal wind towards the constructed QBO time series (based on radiosonde data), which follows the observed zonal wind profile (Giorgetta and Bengtsson, 1999). Three major volcanic eruptions are regarded, which affect the stratospheric aerosol loading and heating rates.

Surface concentrations of $\mathrm{CO}_{2}, \mathrm{CH}_{4}, \mathrm{~N}_{2} \mathrm{O}, \mathrm{CO}$, and 2-D background concentrations of $\mathrm{CFCs}$ are taken into account. Carbon monoxide concentrations are kept constant over the simulation period, since a clear trend over this period is not established (Dameris et al., 2005). Methane surface concentrations are included with a trend, based on observations. Fig. 1a shows the calculated implicit emissions

Table 1

Mean $\mathrm{CO}, \mathrm{CH}_{4}$ and $\mathrm{NO}_{x}$ emissions (in $\mathrm{Tg} / \mathrm{year}$ and $\mathrm{TgN} / \mathrm{year}$ ) for the 4 decades

\begin{tabular}{|c|c|c|c|c|c|c|c|c|c|c|}
\hline \multirow[t]{2}{*}{ Decade } & $\mathrm{CO}$ & $\mathrm{CH}_{4}$ & \multicolumn{2}{|c|}{ Lightning Stratosphere } & Industry & Soil & Biomass burning & Traffic & Ship & Air traffic \\
\hline & \multicolumn{2}{|c|}{$\operatorname{Tg}($ specie $) /$ year } & \multicolumn{8}{|c|}{$\mathrm{TgN} /$ year } \\
\hline $60 \mathrm{~s}$ & 2094 & 515 & 5.23 & 3.31 & 8.09 & 5.60 & 6.40 & 5.16 & 1.36 & 0.12 \\
\hline $70 \mathrm{~s}$ & 2050 & 573 & 5.18 & 3.44 & 10.41 & 5.60 & 6.63 & 6.65 & 2.26 & 0.19 \\
\hline $80 \mathrm{~s}$ & 2012 & 630 & 5.11 & 3.72 & 12.74 & 5.60 & 6.74 & 8.12 & 2.96 & 0.36 \\
\hline $90 \mathrm{~s}$ & 1992 & 662 & 5.05 & 3.82 & 16.46 & 5.60 & 6.99 & 10.50 & 3.13 & 0.59 \\
\hline
\end{tabular}

$\mathrm{CO}$ and $\mathrm{CH}_{4}$ emissions are deduced from their boundary conditions. 

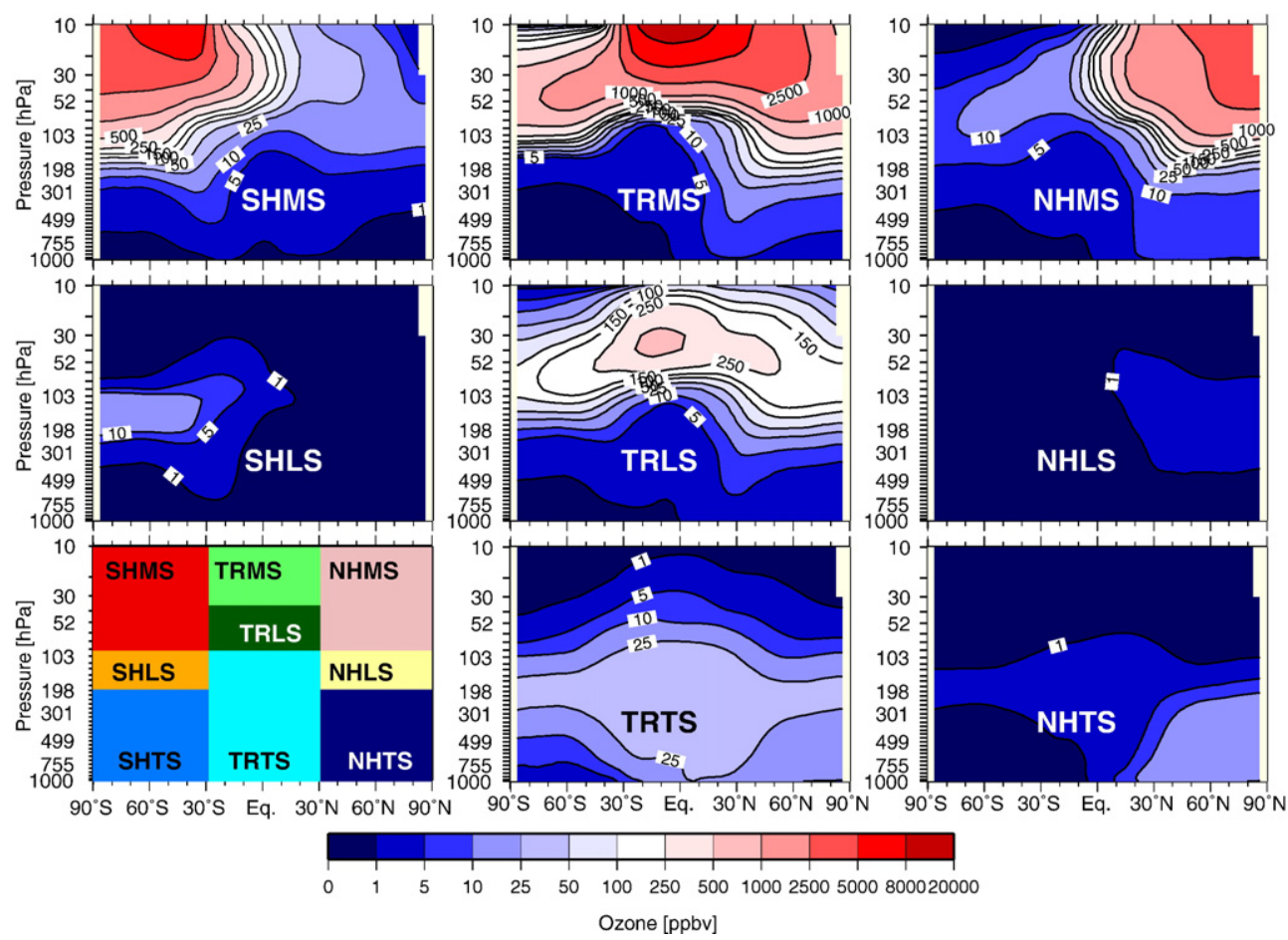

Fig. 2. Decomposition [ppbv] of the zonal mean simulated ozone into nine ozone fields representing ozone produced in nine different regions. The nine regions are displayed lower left and abbreviated with four letters: the first two describe Southern Hemisphere (SH), Tropics (TR), and Northern Hemisphere (NH) and the second two letters Mid-Stratosphere (MS), Lower Stratosphere (LS), and Troposphere (TS), respectively. The classification of the regions is given in the lower left part. Figure is adapted from Grewe (2006).

of $\mathrm{CO}$ and $\mathrm{CH}_{4}$ for 1960 to 1999 , which can be deduced from boundary conditions. Methane emissions show an increase in emissions from $515 \mathrm{Tg} /$ year to $662 \mathrm{Tg} /$ year and carbon monoxide a decrease from 2094 to $1992 \mathrm{Tg} /$ year. The absolute values and also the trend in $\mathrm{CH}_{4}$ emissions are comparable to emission estimates (e.g. 500 to $600 \mathrm{Tg} /$ year $\mathrm{CH}_{4}$ and $2800 \mathrm{Tg} /$ year $\mathrm{CO}$ in the late 90s, Prather et al., 2001; $2.7 \mathrm{Tg} /$ year $\mathrm{CH}_{4}$ increase from 1979 to 1993 , Dentener et al., 2003). Whereas the decrease in CO emissions reflect a decrease in $\mathrm{CO}$ and $\mathrm{CH}_{4}$ lifetime due to a simulated $\mathrm{OH}$ increase. The change of the $\mathrm{CH}_{4}$ lifetime is comparable to previous studies. E.g. Dentener et al. (2003) show a decrease from 1975 to 1993 of around 0.4 years, though they find a longer total lifetime of around 9.2 years.

Emissions of $\mathrm{NO}_{x}$ (Table 1, Fig. 1b) are either prescribed (biomass burning, land traffic, ships, soils, industry, and air traffic) or calculated on-line (lightning, stratospheric production). Lighting $\mathrm{NO}_{x}$ emissions are calculated based on the strength of the convective mass flux and depth of convective clouds (Grewe et al., 2001), latter to prevent lightning in shallow convection.

\section{Methodologies}

In order to separate processes affecting the ozone concentration two different methodologies are applied: (1) An $\mathrm{NO}_{x}$-ozone tracking diagnostic (Grewe, 2004) and (2) ozone origin diagnostic (Grewe, 2006). For the $\mathrm{NO}_{x}$-ozone tracking diagnostic 8 sources for $\mathrm{NO}_{x}$ are specified (lightning, biomass burning, soils, industry, land transportation, ships, air traffic and stratospheric $\mathrm{N}_{2} \mathrm{O}$ degradation). To each of these sources an $\mathrm{NO}_{y}$ tracer is assigned in addition to the chemical species in the module CHEM, which experiences its specific emission and $\mathrm{NO}_{y}$ loss terms proportional to the total $\mathrm{NO}_{y}$ loss. To each $\mathrm{NO}_{y}$ tracer an ozone tracer is assigned, which experiences an ozone production proportional to the ratio of specific $\mathrm{NO}_{y}$ to total $\mathrm{NO}_{y}$ concentration multiplied by the total ozone production via the reaction of $\mathrm{NO}+\mathrm{HO}_{2} \rightarrow \mathrm{NO}_{2}+\mathrm{OH}$. A further ozone tracer is included to account for ozone production by $\mathrm{O}_{2}$ photolysis (mainly stratosphere). The determination of contributions from different sources to ozone is anything but straight forward. Perturbation studies (e.g. $5 \%$ or $30 \%, 100 \%$ changes in each emission category) include non-linear impacts, e.g. from 
wash-out or chemistry, the sum rarely yields $100 \%$ in $\mathrm{NO}_{x}$ and $\mathrm{NO}_{y}$ (e.g. Grewe et al., 2001; Grewe, 2004) distributions. A direct comparison of attributions of ozone based on $5 \%$ emission change and this tagging diagnostic show for most emissions and regions a difference in the order of $5 \%$. Around the tropopause differences reach up to $20 \%$ for lightning (Grewe, 2004). However, the detection of changes in the attribution caused by changes in emissions by $5 \%$ lead to a much better agreement of the two diagnostics with a difference of less than $0.2 \%$ for most regions and less than $0.7 \%$ at the tropopause region. Lamarque et al. (2005) applied a more sophisticated tagging method, including all nitrogen-containing species. They yielded an accuracy of more than $95 \%$ on monthly timescales, which is obviously superior to the diagnostic used here. However, the mentioned diagnostic is computationally too expensive to be included on-line for the whole simulation period and for a detection of attribution changes the method used here is regarded to give reasonable results. A detailed description of the error analysis can be found in Grewe (2004).

The second diagnostic is applied to identify regions of ozone production. The idea is similar to the previous. Nine regions are defined (Fig. 2) to which an ozone tracer is linked. Each tracer experiences ozone production in this region only, and ozone losses in the whole model domain proportional to its concentration. In contrast to the first diagnostic, this one is linear (e.g. transport operator is linear; deposition is linear) and therefore theoretically accurate. However, the transport scheme can introduce numerical diffusion, which is non-linearly dependent on the tracer concentration and may lead to an error of $2 \%$ in the troposphere (Grewe, 2006).

For both diagnostics, the sum of all ozone tracers equals the simulated ozone field. Therefore, the diagnostics allow the interpretation, how much of the ozone is produced by a specific $\mathrm{NO}_{x}$ emission source (1st diagnostic) and where the ozone is actually produced (2nd diagnostic). The first diagnostic is included on-line in the model simulation. The second diagnostic is applied in steady state simulations and has been analysed in detail elsewhere (Grewe, 2006).

\section{The role of the stratosphere and stratospheric influx}

The lifetime of ozone in the stratosphere varies from region to region. In the mid-tropical stratosphere, its lifetime is short and ozone is mainly chemically
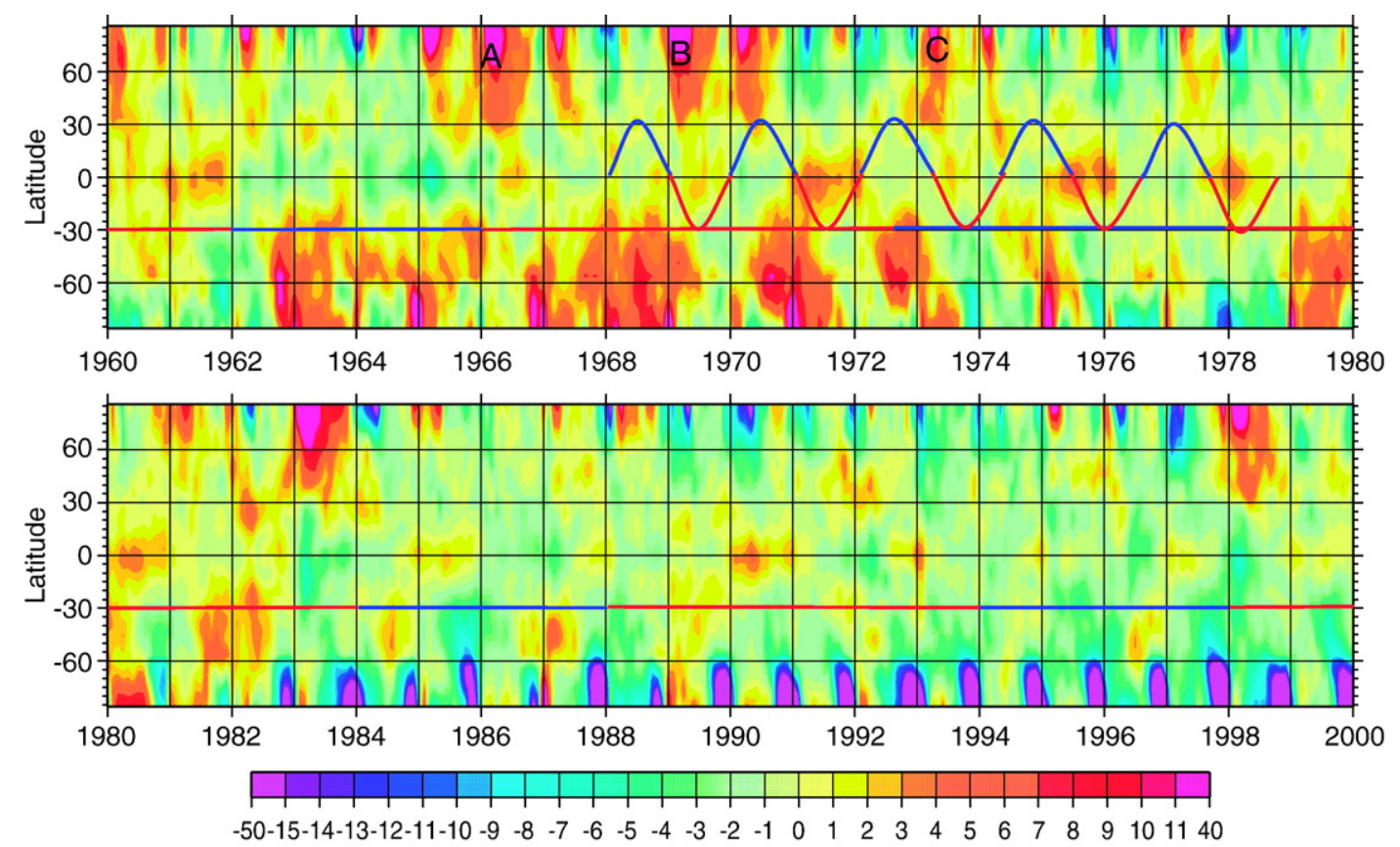

[\%]

Fig. 3. De-seasonalized zonal mean simulated total ozone field [\%] from 1960 to 1999, as an anomaly to mean of the period 1964 to 1980 . Figure adapted from Dameris et al. (2005). At $30^{\circ} \mathrm{S}$ a red (blue) straight line indicates solar activity, exceeding (falling below) a threshold of $100 \times 10^{-22} \mathrm{~W}$ $\mathrm{m}^{-2} \mathrm{~Hz}^{-1}$. The phase of the QBO is indicated between 1968 and 1978 by red (west phase) and blue curves (east phase). (For interpretation of the references to colour in this figure legend, the reader is referred to the web version of this article.) 
controlled. At high latitudes and at tropopause levels, dynamics control the distribution. Therefore, the ozone column is characterized by either pattern of variability, chemically and dynamically induced. An overview of those effects present in the simulation 1960 to 1999 can be found in Dameris et al. (2005). Since the variability of stratospheric ozone introduces variability in tropospheric ozone, their main results are briefly summarised in the following (Fig. 3). On the Northern Hemisphere a high inter-annual variability can be found, which is in reasonable agreement with observational data. The large variability is mainly caused by propagating planetary waves, which are less present in the Southern Hemisphere. The Antarctic ozone hole is clearly visible from the beginning of the 80 s with values below $150 \mathrm{DU}$ (see areas of less than $-15 \%$ in Fig. 3 ) in the 90 s. A detailed discussion is given by Dameris et al. (2005) and Steinbrecht et al. (2006): The 11-year solar cycle can be identified in the tropics with higher ozone values at solar maximum (indicated by red line at $30^{\circ} \mathrm{S}$ in Fig. 3), e.g. 1978-1984 (2 $\sigma$ represents around 5-10 DU or around $\pm 1 \%$ ). During the westerly phase of the QBO (indicated by red curved line in Fig. 3) higher total ozone values are simulated, because the induced secondary circulation reduces the tropical ascent $(2 \sigma$ represents around $10 \mathrm{DU}$, or $\pm 1.5 \%$ for the $90 \mathrm{~s}$ and double the value in the $80 \mathrm{~s}$ ). These results compare well with observational data, which show an amplitude of around 5 DU for the solar cycle and 10 DU for the QBO (Steinbrecht et al., 2006).

The variation in stratospheric ozone also affects the ozone influx into the troposphere. Fig. 4a shows the

a

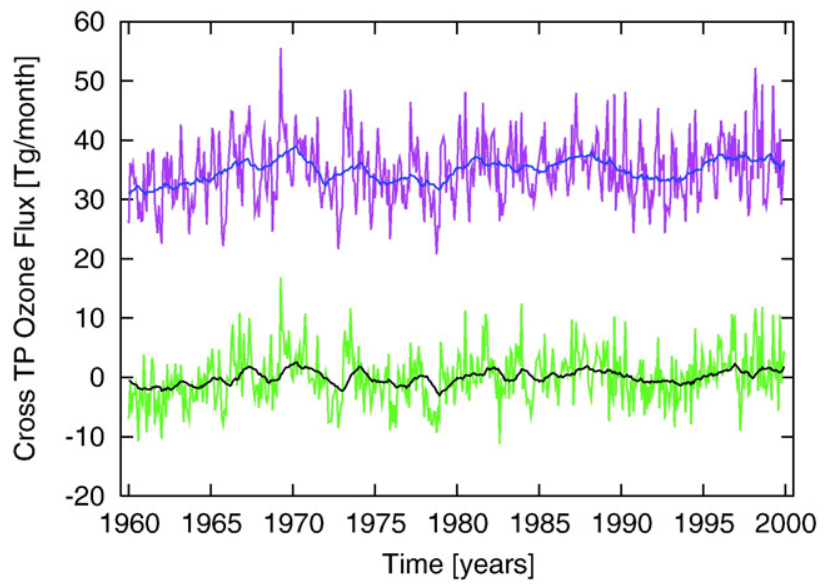

b

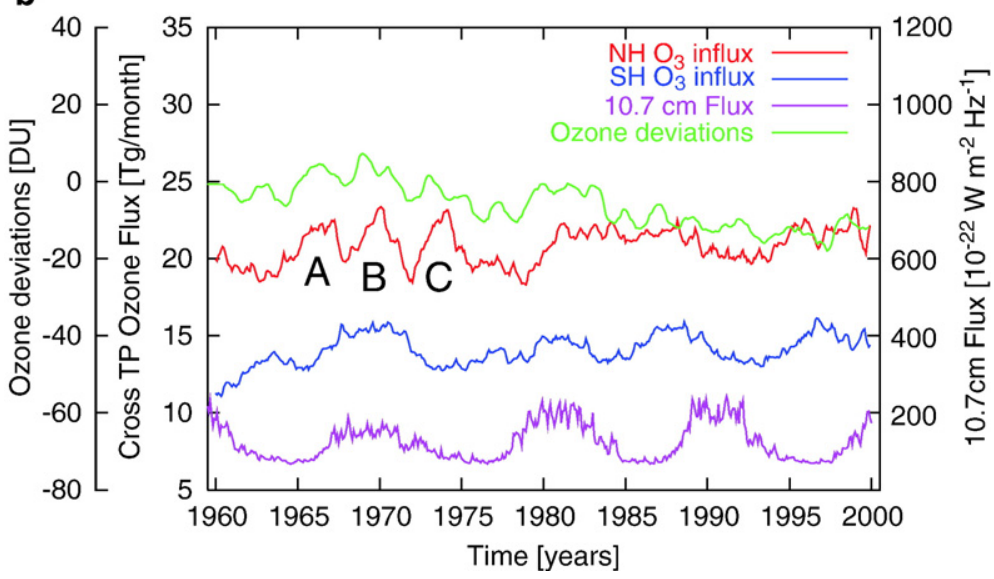

Fig. 4. a) Simulated monthly mean cross tropopause ozone flux [Tg/month] (magenta) and a 25 -month running mean (blue). The green line shows the de-seasonalized flux with a running mean overlaid (black line). b) red and blue curves mark the Northern and Southern Hemisphere contributions [Tg/month], respectively. Total global ozone anomalies [DU] (green) and the $10.7 \mathrm{~cm} \mathrm{flux}\left[10^{-22} \mathrm{~W} \mathrm{~m}^{-2} \mathrm{~Hz}^{-1}\right.$ ] (magenta) are added. (For interpretation of the references to colour in this figure legend, the reader is referred to the web version of this article.) 

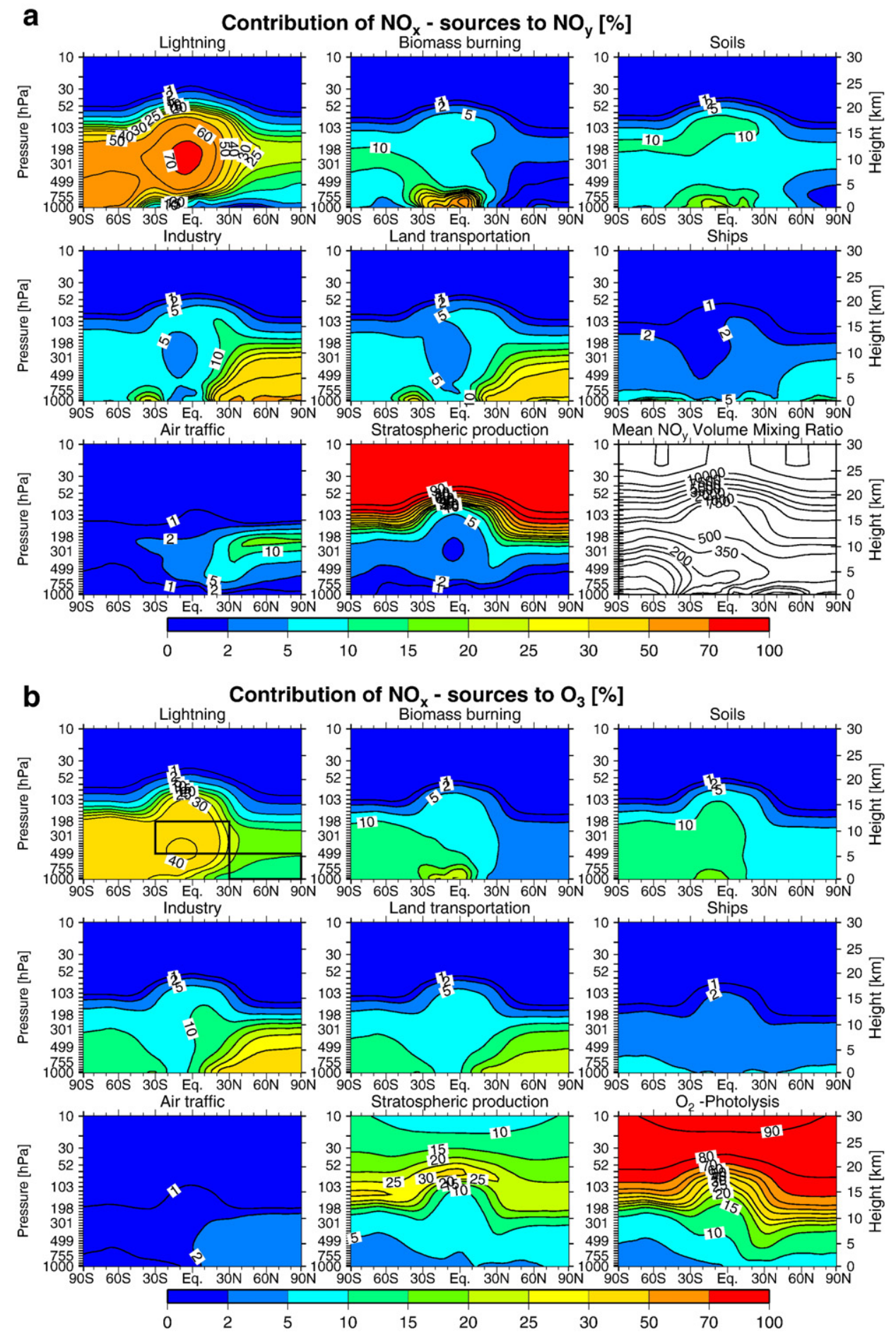

Fig. 5. Decomposition [\%] of the zonal and decadal (1990-1999) mean simulated $\mathrm{NO}_{y}$ (a) and ozone (b) according to their sources: lightning, biomass burning, soils, industry, surface traffic, ships, air traffic, stratospheric production of nitrogen. For ozone, its production caused by oxygen photolysis is added, whereas in (a) the mean $\mathrm{NO}_{y}$ distribution is added. Boxes in (b) mark areas further discussed in the text: Tropical upper troposphere: $30^{\circ} \mathrm{S}-30^{\circ} \mathrm{N} ; 500$ to $200 \mathrm{hPa}$ and northern extra-tropical lower troposphere: $30^{\circ} \mathrm{N}-90^{\circ} \mathrm{N}$; 1000 to $500 \mathrm{hPa}$. 
ozone flux calculated by applying the formula presented in Wei (1987) (also described in Grewe and Dameris, 1996). The total amount of the ozone flux into the troposphere of around $420 \mathrm{Tg}$ per year is in good agreement with observational data (e.g. Murphy and Fahey, 1994: $475 \mathrm{Tg} / \mathrm{a}$; Olsen et al., 2004: $500 \mathrm{Tg} / \mathrm{a}$ ), though the method includes a number of uncertainties (see Discussion section). The decomposition of the total flux into Northern and Southern Hemisphere contributions (Fig. 4b) shows that the 11-year solar cycle can be identified in the Southern Hemisphere from 1960 to 1985, whereas in the Northern Hemisphere the planetary wave activity dominates the variability. Episodes with enhanced ozone values (around 1966, 1969/70 and 1973, see A, B, and C in Figs. 3 and 4b) lead to enhanced ozone influx. The interannual variability of the global mean influx, in terms of min-max values, amounts to $\pm 10 \mathrm{Tg}$ / month, which is around $\pm 30 \%$ of the mean value.

Fig. 2 shows how the individual ozone origin tracers are transported through the atmosphere and how they are chemically destroyed. Note that stratospheric ozone transported into the troposphere is not only produced in the region TRMS (tropical mid-stratosphere), but also, and even with a higher contribution, from the region NHMS (Northern Hemisphere mid-stratosphere). In the tropical troposphere local ozone production is the dominant source.

By applying this ozone origin diagnostic and calculating the tropospheric influx of these tracers, the origin of ozone can be identified and the source of variations in the ozone influx explained (Fig. 10 in Grewe, 2006): On the Northern Hemisphere the ozone influx mainly originates from the regions NHMS (Northern Hemisphere mid-stratosphere), TRMS (tropical mid-stratosphere), and TRTS (tropical troposphere). Since the NHMS is characterized by a large year-to-year variability, also the Northern Hemisphere ozone influx experiences this variability. The Southern Hemisphere ozone influx originates mainly from the regions TRTS (tropical troposphere), SHMS (Southern Hemisphere mid-stratosphere), and TRLS (tropical lower stratosphere). The year-to-year variability of ozone in the SHMS region is much lower than in the NHMS region, because of smaller planetary wave activity, which leads to smaller variations in ozone from the SHMS region. Instead, the variability induced by the 11-

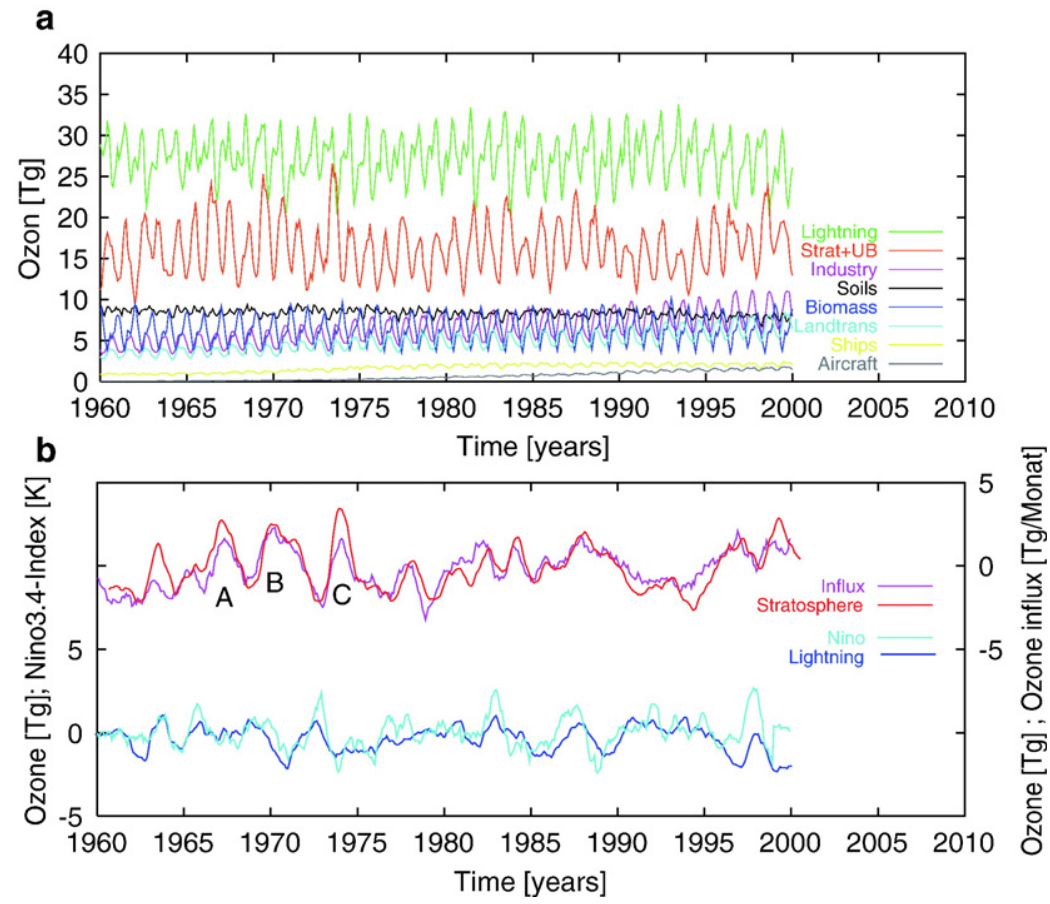

Fig. 6. Upper troposphere tropical $\left(30^{\circ} \mathrm{S}-30^{\circ} \mathrm{N} ; 500\right.$ to $\left.200 \mathrm{hPa}\right)$ ozone budgets [Tg]. Top: Decomposition into various ozone sources (see Fig. 5). Bottom: Major contributions to ozone variability. De-seasonalized anomalies [Tg] for stratospheric ozone (red) and lightning (dark blue) after applying a 25-month running mean. Overlaid are the stratospheric ozone influx [Tg/month] (magenta; see also Fig. 4) and the El-Niño3.4 Index [K] (light blue), which represents a temperature deviation in the area $5^{\circ} \mathrm{S}-5^{\circ} \mathrm{N}$ and $170^{\circ} \mathrm{W}-120^{\circ} \mathrm{W}$. (For interpretation of the references to colour in this figure legend, the reader is referred to the web version of this article.) 
year solar cycle is dominating the variability of ozone at timescales exceeding 2 years in the SHMS and consequently also in the Southern Hemisphere ozone influx.

\section{Tropospheric variability}

Fig. 5a and $\mathrm{b}$ show the annual mean contributions from various sources to the $\mathrm{NO}_{y}$ and ozone concentration, respectively for the last decade (1990-1999) simulated. Clearly, lightning is the dominant source for $\mathrm{NO}_{y}$ (up to $70 \%$ ) and ozone (up to $40 \%$ ) in the tropics and Southern Hemisphere. Industry and surface transportation $\mathrm{NO}_{x}$ emissions are the most dominant sources for $\mathrm{NO}_{y}$ and ozone at Northern mid- and high latitudes.

The variability of ozone concentrations in the troposphere is influenced by both stratospheric and tropospheric processes. The discussion will focus on two regions: the tropical upper troposphere and the Northern Hemisphere lower troposphere, marked as black boxes in Fig. 5b. Fig. 6 shows the temporal development of ozone in the tropical upper troposphere, including the ozone partitioning resulting from the various $\mathrm{NO}_{x}$ emissions derived by the $\mathrm{NO}_{x}$-ozone diagnostic (Section 3). Clearly, lightning $\mathrm{NO}_{x}$ emissions dominate the ozone concentration in that region. Stratospheric ozone (red curve) is the second most important contributor, followed (only in the 90s) by industrial emissions. The inter-annual variability is induced by lightning occurrence and stratospheric dynamics. Other processes leading to a year to year variability are underestimated, since most of the surface $\mathrm{NO}_{x}$ emissions included in the model do not have an interannual variability, e.g. for anthropogenic emissions from industry only a stepwise linear increase in the global emission rate is assumed. The lower panel of Fig. 6 (bottom) shows the de-seasonalized ozone changes from lightning $\mathrm{NO}_{x}$ emissions and stratospheric influx. Additionally the ozone influx (see also Fig. 4) and the El Niño index (temperature deviation in the midtropical Pacific; values greater than $0.4 \mathrm{~K}$ and less than $-0.4 \mathrm{~K}$ represent El Niño and La Niña situations, respectively, e.g. Trenberth, 1997) are shown. In the upper troposphere, ozone labelled as of stratospheric origin follows the ozone influx. This implies that the variability of ozone in the tropical upper troposphere can directly be attributed to the variability of the Northern

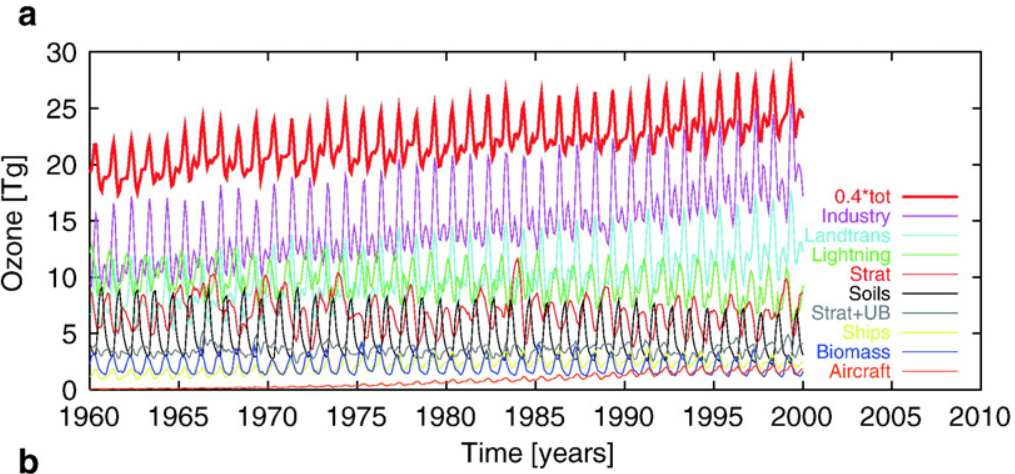

b

Time [years]

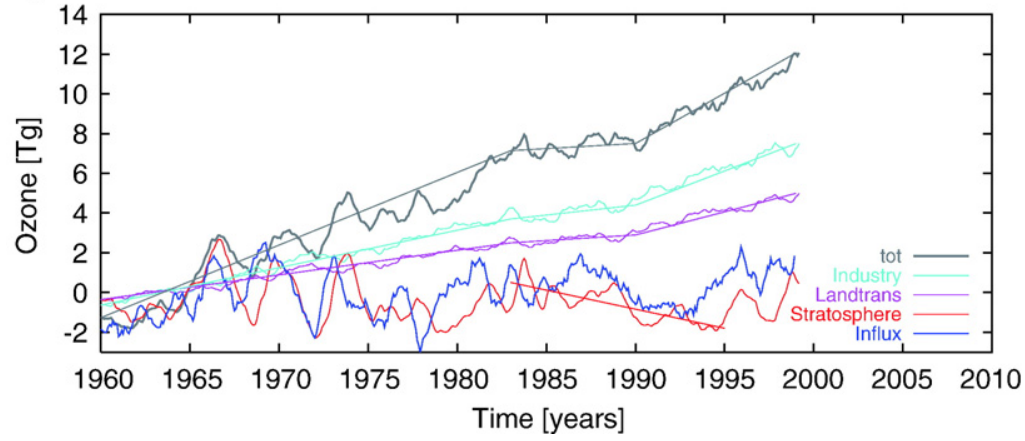

Fig. 7. Lower troposphere Northern Hemisphere $\left(30^{\circ} \mathrm{N}-90^{\circ} \mathrm{N} ; 1000\right.$ to $\left.500 \mathrm{hPa}\right)$ ozone budgets [Tg]. Top: De-composition into various ozone sources (see Fig. 5). Bottom: Major contributions to ozone trends. De-seasonalized anomalies [Tg] for stratospheric ozone (red), industry (blue), surface traffic (magenta) and total ozone (grey). Overlaid in blue are the Northern Hemisphere ozone influx anomalies [Tg/month]. Piecewise trend lines are added. (For interpretation of the references to colour in this figure legend, the reader is referred to the web version of this article.) 
Hemisphere mid-stratosphere dynamics, e.g. individual years with large influxes during the $60 \mathrm{~s}$ and $70 \mathrm{~s}$ (A: $\sim 1966$; B: $\sim 1969 / 70$; C: $\sim 1973$; Fig. $6 b)$. This correlates well with high positive anomalies of Northern Hemisphere extra-tropical ozone (Fig. 3). This is also true for the solar cycle, with high solar activity around 1970, 1980 and 1999. The influence of stratospheric dynamics on the inter-annual variability of ozone is in the order of $\pm 5 \%$, whereas the influence of the El Niño phenomenon on the inter-annual variability of ozone is in the order of $\pm 3 \%$.

In the Northern Hemisphere lower troposphere (Fig. 7a), the ozone concentration is dominated by emissions from industry $(\sim 15 \mathrm{Tg})$, surface traffic $(\sim 12 \mathrm{Tg})$, lightning $(\sim 10 \mathrm{Tg})$ and stratospheric intrusion $(\sim 7 \mathrm{Tg})$, whereas interannual variability (Fig. 7b) is dominated mainly by the stratospheric intrusions. This partly may be due to the lack of interannual variability in the emission data. The ozone increase of around $25 \%$ in 1999 with respect to the $60 \mathrm{~s}$ results mainly from the increase in emissions from industry $(20 \%)$ and surface traffic $(10 \%)$. The increase shows a stepwise behaviour, with almost constant annual mean values during the $80 \mathrm{~s}$. This has two reasons: First, the anthropogenic $\mathrm{NO}_{x}$ emissions included in the model are assumed to have smaller, but still positive, increase rates during that period (Fig. 1b), which is clearly reflected by the ozone changes caused by industrial $\mathrm{NO}_{x}$ emissions (Fig. 7a,b). Second, the ozone contribution from the stratosphere is decreasing by approximately $5 \%$ during that time which is caused by stratospheric ozone depletion. To some extent this offsets the increase in ozone caused by the increase in emissions during that period and therefore the increase is slowed down.

\section{Discussion}

In this paper mainly two aspects were investigated: a) what drives the ozone variability in the tropical upper troposphere? And b) what influences Northern Hemisphere lower troposphere ozone trends? The influence of stratospheric ozone on the troposphere was identified as one important factor for both questions. The impact of changes in stratospheric ozone on tropospheric ozone has been identified from observational data (e.g. Schnell et al., 2001). Taalas et al. (1997) estimated a trend of around $-10 \%$ for the upper troposphere and around $-2 \%$ for the lower troposphere for high latitudes of both hemispheres from 1988 to 1994 , which is comparable to our findings. They suggested an increased penetration of UV fluxes into the troposphere leading to an enhanced chemical activity. This increased UV fluxes were measured at numerous stations (WMO, 2003). Modelling studies suggest that in remote areas with low $\mathrm{NO}_{x}$ values an increase in UV-fluxes decrease surface ozone whereas in polluted regions enhanced ozone production dominates (Isaksen et al., 2005, and references therein). This simulation shows a pronounced ozone deficit on the Southern Hemisphere in 1983 and 1988 (Fig. 3), and an ozone enhancement in 1979 and 1989 in the order of $5 \%$ in both cases. Concurrently, tropospheric ozone production and destruction are both increasing (decreasing), during episodes of low (enhanced) stratospheric ozone. This leads to a decrease (increase) of surface ozone of 5\% (not shown), which is in agreement to e.g. Isaksen et al. (2005). This adds to the contribution originating from strat-trop exchange.

In the tropics an analysis of tropospheric ozone columns, derived from TOMS measurements indicated an anti-correlation with the 11-year solar cycle (Chandra et al., 1999) in the area of the tropical Pacific. This simulation shows for the same region peak values of ozone columns in 1965, 1977, 1987, and 1997 (not shown), which coincides with low solar activity, however delayed by 1 to 2 years. The amplitude is in the order of $0.5 \mathrm{DU}$, which is roughly 5 times smaller than the values estimated by Chandra et al. (1999). Since the correlation is out of phase in the observational and model data, it is suggested that it is driven by changes in UV fluxes which impact ozone chemistry in the marine areas, as described above. On the other hand, the variability of upper troposphere ozone induced by a variability of ozone influxes is in phase.

The determination of the origin of tropospheric ozone with respect to various $\mathrm{NO}_{x}$ sources has previously been performed by others (e.g. Lelieveld and Dentener, 2000; Lamarque et al., 2005), since they took into account all $\mathrm{NO}_{x}$ pathways, their methodology is computationally much more expensive and could only be included for selected years. Lelieveld and Dentener (2000) presented a contribution of lighting to ozone of around $50 \%$ in the upper tropical troposphere and less than $10 \%$ in the northern extra-tropical troposphere for 1993. Although E39/C gives largest contribution to ozone also from lightning (Fig. 5b) the values are smaller, since $\mathrm{NO}_{y}$ and ozone seems to be more effectively transported to higher latitudes through the lowermost stratosphere and upper troposphere (Grewe et al., 2002b). On the other hand, their results indicate a stronger impact of stratospheric ozone especially on the Southern Hemisphere of around 40\%, whereas E39/C shows a contribution of $10 \%$ to $20 \%$. The latter is more in agreement to Lamarque et al. (2005). Other studies 
Table 2

Comparison of the sensitivities in methane and ozone lifetime, ozone loss to changes in the ozone burden and the sensitivity of ozone burden changes to $\mathrm{NO}_{x}$ emissions

\begin{tabular}{|c|c|c|c|c|}
\hline $\begin{array}{l}\text { Changes } \\
\text { per } \mathrm{O}_{3}\end{array}$ & $\mathrm{CH}_{4}$ lifetime & $\mathrm{O}_{3}$ lifetime & $\mathrm{O}_{3}$ loss & $\begin{array}{l}\mathrm{NO}_{x} \\
\text { emission }\end{array}$ \\
\hline $\begin{array}{l}\text { burden } \\
\text { change }\end{array}$ & $\mathrm{a} / \mathrm{TgO}_{3}$ & $\mathrm{~d} / \mathrm{TgO}_{3}$ & $\begin{array}{l}\mathrm{TgO}_{3} / \mathrm{a} / \\
\mathrm{TgO}_{3}\end{array}$ & $\begin{array}{l}\mathrm{TgO}_{3} / \\
(\mathrm{TgN} / \mathrm{a})\end{array}$ \\
\hline
\end{tabular}

$\begin{array}{lllll}\text { Stevenson } & 0.000 \pm 0.006 & -0.021 \pm 0.004 & 18.17 \pm 2.3 & 1.96 \pm 0.37\end{array}$ et al.

(2006)

$\begin{array}{lllll}\text { This work } & -0.007 \pm 0.001 & -0.032 \pm 0.007 & 16.40 \pm 1.2 & 3.15 \pm 0.26\end{array}$

show a contribution from stratospheric ozone to lower tropospheric ozone of 10 to $20 \mathrm{ppbv}(25-35 \%)$ on the Northern Hemisphere and less than 5 to $10 \mathrm{ppbv}$ $(\sim 20 \%)$ on the Southern Hemisphere (Collins et al., 2003; Kentarchos and Roelofs, 2003), respectively. Obviously, a conclusive picture cannot be drawn yet on the absolute and relative impact of various $\mathrm{NO}_{x}$ sources on the $\mathrm{NO}_{y}$ and ozone distribution. However, some general statements can be made: lightning dominates the $\mathrm{NO}_{y}$ and ozone budget in the tropical regions (see also Levy et al., 1999); stratospheric ozone the upper troposphere and anthropogenic $\mathrm{NO}_{x}$ emissions are dominating the production of ozone in the lower troposphere of the northern extra-tropics.

A direct comparison of calculated ozone changes with previous simulations is difficult since time horizons differ. Most model applications investigated pre-industrial and present simulations rather than the transient behaviour during the last decades (e.g. Lelieveld and Dentener, 2000; Hauglustaine and Brasseur, 2001). Others calculated the development from pre-industrial times in steps of 10 years (Lamarque et al., 2005). Stevenson et al. (2006) performed a multi-model analysis for the years 2000 and 2030, which includes a number of sensitivities. These are more suitable to be compared to the findings presented here. Changes in ozone chemistry largely depend on the changes in emissions of its precursors. The present simulation (Table 1) includes an increase in $\mathrm{NO}_{x}$ emissions, a slight decrease in $\mathrm{CO}$ emissions and an increase in $\mathrm{CH}_{4}$ concentrations. The most similar experiments in the work of Stevenson et al. are two timeslice experiments (S1 and S4), in which $\mathrm{NO}_{x}$ emissions increase by $27 \mathrm{TgN}$ (here: $17 \mathrm{TgN}$ ); $\mathrm{CO}$ emissions increase by roughly $60 \%$ (here: $-5 \%$ ) and $\mathrm{CH}_{4}$ surface concentrations increases by $403 \mathrm{ppbv}$ (here $576 \mathrm{ppbv}$ ). Though, it has to be noted that $\mathrm{CO}$ and NMHC emission changes differ significantly, which most likely leads to a reduction in the $\mathrm{OH}$ concentration and a potentially larger methane lifetime change in S4 versus S1 than in this simulation. Table 2 shows that the sensitivity of changes in methane lifetime, ozone lifetime and ozone loss are comparable to the findings of Stevenson et al. The increase of the ozone burden in relation to $\mathrm{NO}_{x}$ emissions is somewhat larger in E39/C. However, the overall picture is consistent taking into account the different experimental set-up. Fig. 8 shows the results in more detail. Clearly, the correlation is weakest for ozone lifetime.

The most prominent variability pattern in the tropical troposphere on annual timescales is the El Niño phenomenon. Ziemke and Chandra (1999) presented its impact on tropospheric ozone derived from TOMS measurements. A clear signal was derived by applying a linear regression model. In order to directly compare their results, Fig. 9 shows monthly

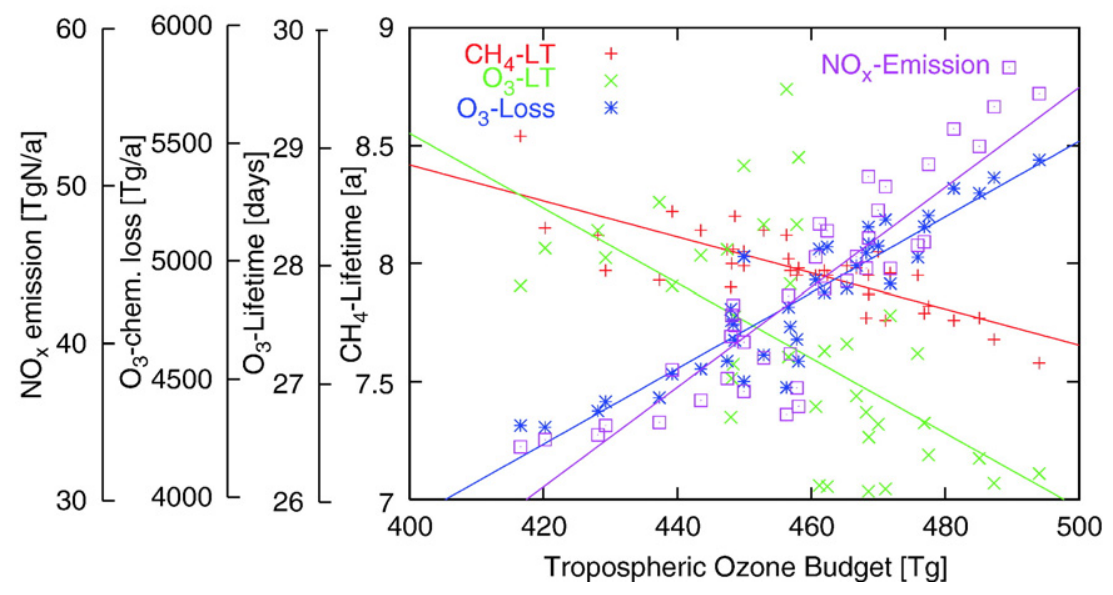

Fig. 8. Correlations of annual mean $\mathrm{NO}_{x}$ emissions [TgN/year], chemical ozone loss [Tg/year], ozone lifetime [days], and methane lifetime [years] to the tropospheric ozone budget $[\mathrm{Tg}]$. 


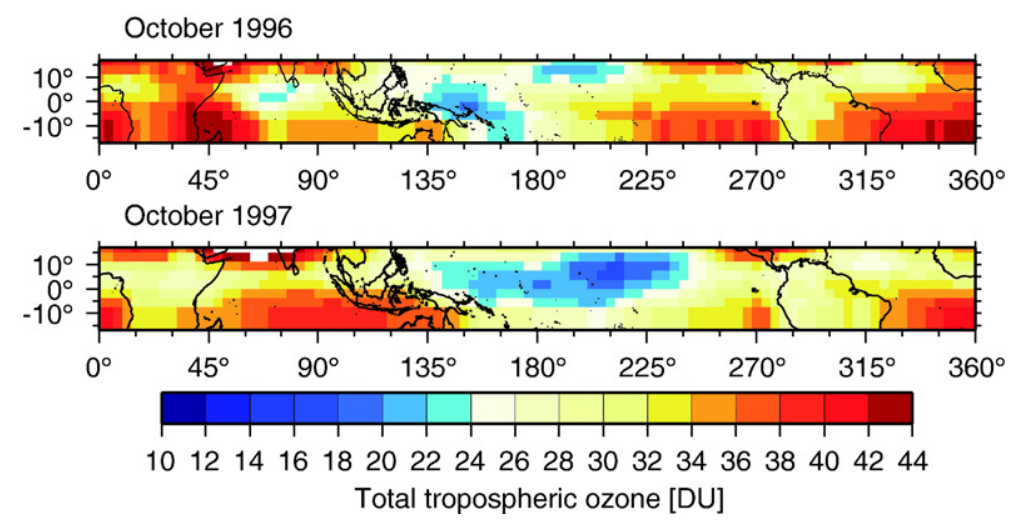

Fig. 9. Simulated tropospheric ozone columns for October 1996 (top) and 1997 (bottom) [DU], representing a non-El Niño year and an El Niño year.

means of simulated tropospheric ozone columns for October 1996 (normal) and 1997 (El Niño), which can be compared directly to their Plate 1 . They found an eastward shift of minimum tropospheric total ozone values of 20 to $22 \mathrm{DU}$ in the Pacific; a maximum westwards of Indonesia, which is well simulated by the model, i.e. the model is able to correctly simulate the principal impact of circulation changes on tropospheric ozone. Similar results were presented by Steinbrecht et al. (2006), who showed that the model is able to reproduce ENSO induce total ozone changes. Doherty et al. (2006) showed that tropical lightning $\mathrm{NO}_{x}$ emissions are correlated to the ENSO index, which agree with the findings presented here, though, they applied a lightning parameterisation, which has a very low sensitivity on marine lightning.

\section{Summary}

The atmospheric concentration of ozone shows a large variability in many parts of the atmosphere. To better understand the driving factors for this variability and to be able to attribute changes to natural climate variability and to anthropogenic changes a multidecadal simulation (1960 to 1999) has been performed, employing realistic natural forcings, like El Niño, QBO, volcanoes, solar cycle. Additionally, diagnostic tools have been applied to attribute ozone changes and variations to specific $\mathrm{NO}_{x}$ and ozone sources and to detect the regions from where this ozone originates.

It has been shown that the stratospheric dynamics and the main stratospheric ozone variability pattern are well reproduced (Dameris et al., 2005, 2006; Steinbrecht et al., 2006). A total trend of approximately -20 DU is simulated, which mainly results from CFC emissions. A part $(15 \%)$ of this decrease can be attributed to a moistening of the stratosphere caused by tropospheric warming (Stenke and Grewe, 2005).

The influx of ozone from the stratosphere into the troposphere depends on the stratospheric circulation and the chemical stratospheric ozone production. Applying ozone origin diagnostics leads to the result that the variability of the ozone influx into the troposphere on the Northern Hemisphere is dominated by planetary wave forcing and on the Southern Hemisphere by variations of the ozone production caused by the solar cycle. This directly produces inter-annual variability in tropospheric ozone of around $\pm 5 \%$, which is most pronounced in the tropics. Another climate variability pattern is forced by the El Niño phenomenon, which increases lightning occurrence and lightning $\mathrm{NO}_{x}$ emissions and leads to an inter-annual ozone variability of around $\pm 3 \%$ in the tropical upper troposphere.

The analysis of the ozone influx is based on the Wei formula, which has been under debate, since the net flux is a residuum and depends additionally on the coordinate system (Grewe and Dameris, 1996; Wirth and Egger, 1999; Stohl et al., 2003). However, the results show that the variability in the ozone influx is well correlated with the variability in tropospheric ozone originating from the stratosphere, which gives more confidence in the methodology.

In the Northern Hemisphere lower troposphere, i.e. the region which is related to air quality aspects, ozone is mainly produced by industry and surface traffic $\mathrm{NO}_{x}$ emissions. Since the prescribed anthropogenic emissions include an increase during the simulation period, also the ozone produced by those emissions shows a similar behaviour, i.e. a total increase of $25 \%$ (relative to the total ozone) with $20 \%$ caused by industry $\mathrm{NO}_{x}$ emissions and $10 \%$ by surface $\mathrm{NO}_{x}$ traffic emissions. During the $80 \mathrm{~s}$ and early $90 \mathrm{~s}$ the increase in ozone is 
decelerated, because the contribution from the stratospheric influx is reduced by $5 \%$ (with respect to total ozone) due to stratospheric ozone depletion.

Since reliable global emission data were not available at the time when the simulation was started, the results are clearly limited by the rather coarse assumptions concerning the anthropogenic emissions. The emission data reflect a compromise between global emission increase in the 90s and European $\mathrm{NO}_{x}$ emission reduction, i.e. a decelerated global increase. Moreover, non-methane hydrocarbon emissions are not included in the model simulation and even more important the tropospheric chemistry consists of $\mathrm{CH}_{4}-\mathrm{OH}-\mathrm{NO}_{x}-\mathrm{O}_{3}$ background chemistry, only. Previous studies clearly pointed out that this is a limitation to the applicability of the model (Granier and Brasseur, 2003; Matthes et al., 2005). It implies that ozone lifetimes are overestimated in the lowermost atmosphere, where the NMHC chemistry is most important (Roelofs and Lelieveld, 2000). Further, the missing NMHC chemistry leads to an ozone change pattern, which is more confined to the source regions in the present simulation. Moreover the road traffic NMHC emissions would even enhance the long-range transport of nitrogen compounds via formation of additional PAN (Matthes et al., 2005). However, the less confined change pattern expected due to PAN formation and the shorter ozone lifetime caused by an increase in $\mathrm{HO}_{2}$ due to NMHC chemistry are counteracting processes. NMHC chemistry is not included in the present simulation and both processes somehow compensate, but for the wrong reason. The background chemistry included in this simulation describes well enough the chemistry at least in the mid- and upper troposphere. Background chemistry is sufficient to investigate how variability in stratospheric ozone, caused by dynamics or the 11-year solar cycle, and variability in tropospheric dynamics (El Niño) impact tropospheric ozone and its trend. For a reliable estimate of road traffic and industry emissions a more sophisticated chemical scheme and emission data (e.g. recently released data from the RETRO EU project) have to be employed.

However, the results clearly indicate that the near surface ozone burden, which is an air quality aspect, is to some extent affected by stratospheric processes and that ozone trends can be weakened and strengthened by stratospheric processes and climate-chemistry interactions (e.g. El Niño).

The simulation does not include small scale processes, normally resolved by air quality/regional models. A number of feedbacks are possible, such as plume conversion processes in the vicinity of cities, etc. It will be a challenge to include these effects in future climate-chemistry simulations.

\section{Acknowledgement}

This study has been supported by the EU Network of Excellence (NoE) ACCENT. I like to thank Martin Dameris and Christine Fichter for the helpful discussions.

\section{References}

Austin J, Shindell D, Beagley SR, Brühl C, Dameris M, Manzini E, et al. Uncertainties and assessments of chemistry-climate models of the stratosphere. Atmos Chem Phys 2003;3:1-27.

Brunner D, Staehelin J, Rogers HL, Köhler MO, Pyle JA, Hauglustaine D, et al. An evaluation of the performance of chemistry transport models by comparison with research aircraft observations. Part 1: concepts and overall model performance. Atmos Chem Phys 2003;3:1609-31.

Brunner D, Staehelin J, Rogers H, Köhler M, Pyle J, Hauglustaine D, et al. Atmospheric chemistry and physics, an evaluation of the performance of chemistry transport models - Part 2: detailed comparison with two selected campaigns. Atmos Chem Phys 2005;5: $107-29$

Chandra S, Ziemke JR, Stewart RW. An 11-year solar cycle in tropospheric ozone from TOMS measurements. Geophys Res Lett 1999;26(2):185-8. doi:10.1029/1998GL900272.

Collins WJ, Derwent RG, Garnier B, Johnson CE, Sanderson MG, Stevenson DS. Effect of stratosphere-troposphere exchange on the future tropospheric ozone trend. J Geophys Res 2003;108 (D12):8528. doi:10.1029/2002JD002617.

Dameris M, Grewe V, Ponater M, Deckert R, Eyring V, Mager F, et al. Long-term changes and variability in a transient simulation with a chemistry-climate model employing realistic forcings. Atmos Chem Phys 2005;5:2121-45.

Dameris M, Matthes S, Deckert R, Grewe V, Ponater M. Solar cycle effect delays onset of ozone recovery. Geophys Res Lett 2006;33: L03806. doi:10.1029/2005GL024 741.

Dentener F, van Weele M, Krol M, Houweling S, van Velthoven P. Trends and inter-annual variability of methane emissions derived from 1979-1993 global CTM simulations. Atmos Chem Phys 2003;3:73-88.

Derwent RG, Simmonds PG, Seuring S, Dimmer C. Observation and interpretation of the seasonal cycles in the surface concentrations of ozone and carbon monoxide at mace head, Ireland from 1990 to 1994. Atmos Environ 2004;32:4769-78.

Doherty RM, Stevenson DS, Johnson CE, Collins WJ, Sanderson MG. Tropospheric ozone and El Niño-Southern Oscillation: influence of atmospheric dynamics, biomass burning emissions, and future climate change. J Geophys Res 2006;111:D19304. doi:10.1029/ 2005JD006849.

Dunkerton T. On the mean meridional mass motions of the stratosphere and mesosphere. J Atmos Sci 1978;35:2325-33.

Giorgetta M, Bengtsson L. Potential role of the quasi-biennial oscillation in the stratosphere-troposphere exchange as found in water vapor in general circulation model experiments. J Geophys Res 1999;104:6003-20.

Granier C, Brasseur G. The impact of road traffic on global tropospheric ozone. Geophys Res Lett 2003;30:1086. doi:10.1029/ 2002GL015972.

Grewe V. Technical note: a diagnostic for ozone contributions of various $\mathrm{NO}_{x}$ emissions in multi-decadal chemistry-climate model simulations. Atmos Chem Physc 2004;4:729-36.

Grewe V. The origin of ozone. Atmos Chem Phys 2006;6:1495-511. 
Grewe V, Dameris M. Calculating the global mass exchange between stratosphere and troposphere. Ann Geophys 1996;14:431-42.

Grewe V, Brunner D, Dameris M, Grenfell JL, Hein R, Shindell D, et al. Origin and variability of upper tropospheric nitrogen oxides and ozone at northern mid-latitudes. Atmos Environ 2001;35: 3421-33.

Grewe V, Dameris M, Fichter C, Sausen R. Impact of aircraft $\mathrm{NO}_{x}$ emissions. Part 1: interactively coupled climate-chemistry simulations and sensitivities to climate-chemistry feedback, lightning and model resolution. Meteorol Z 2002a;3:177-86.

Grewe V, Reithmeier C, Shindell DT. Dynamic-chemical coupling of the upper troposphere and lower stratosphere region. Chemosphere Glob Chang Sci 2002b;47:851-61.

Hauglustaine DA, Brasseur GP. Evolution of tropospheric ozone under anthropogenic activities and associated radiative forcing of climate. J Geophys Res 2001;106(D23):32337-60. doi:10.1029/ 2001JD900175.

Hein R, Dameris M, Schnadt C, Land C, Grewe V, Köhler I, et al. Results of an interactively coupled atmospheric chemistry-general circulation model: comparison with observations. Ann Geophys 2001;19:435-57.

Isaksen ISA, Zerefos C, Kourtidis K, Meleti C, Dalsøren SB, Sundet $\mathrm{JK}$, et al. Tropospheric ozone changes at unpolluted and semipolluted regions induced by stratospheric ozone changes. J Geophys Res 2005;110:D02302. doi:10.1029/2004JD004618.

Jonson JE, Simpson D, Fagerli H, Solberg S. Can we explain the trends in European ozone levels? Atmos Chem Phys 2006;6:51-66.

Kentarchos AS, Roelofs GJ. A model study of stratospheric ozone in the troposphere and its contribution to tropospheric $\mathrm{OH}$ formation. J Geophys Res 2003;108(D12):8517. doi:10.1029/ 2002JD002598.

Lamarque J-F, Hess P, Emmons L, Buja L, Washington W, Granier C. Tropospheric ozone evolution between 1890 and 1990. J Geophys Res 2005;110:D08304. doi:10.1029/2004JD005537.

Land C, Ponater M, Sausen R, Roeckner E. The ECHAM4.L39(DLR) atmosphere GCM, technical description and climatology, DLRForschungsbericht 1991-31. Köln, Germany. ISSN:1434 -8454 : Deutsches Zentrum für Luft- und Raumfahrt; 1999. 45 pp.

Lelieveld J, Dentener FJ. What controls tropospheric ozone? J Geophys Res 2000;105(D3):3531-52. doi:10.1029/1999JD901011.

Levy II H, Moxim WJ, Klonecki AA, Kasibhatla PS. Simulated tropospheric $\mathrm{NO}_{x}$ : its evaluation, global distribution and individual source contributions. J Geophys Res 1999;104(D21):26279-306. doi:10.1029/1999JD900442.

Logan JA, Megretskaia IA, Miller AJ, Tiao GC, Choi D, Zhang L, et al. Trends in the vertical distribution of ozone: a comparison of two analyses of ozonesonde data. J Geophys Res 1999;104 (D21):26373-400. doi:10.1029/1999JD900300.

Matthes S, Grewe V, Sausen R, Roelofs G-J. Global impact of road traffic emissions on tropospheric ozone. Atmos Chem Phys Diss 2005;5:10339-67.

Monks PS. A review of the observations and origins of the spring ozone maximum. Atmos Environ 2000;34:3545-61.

Murphy DM, Fahey DW. An estimate of the flux of stratospheric reactive nitrogen and ozone into the troposphere. J Atmos Sci 1994;51:654-73.

Olsen MA, Schoeberl MR, Douglass AR. Stratosphere-troposphere exchange of mass and ozone. JGR 2004;109. doi:10.1029/ 2004JD005186.

Oltmans II SJ, Galbally IE, Brunke E-G, Meyer CP, Lathrop JA, Johnson BJ, et al. Trends of ozone in the troposphere. Geophys Res Lett 1998;25(2):139-42. doi:10.1029/97GL03505.
Oltmans SJ, Lefohn AS, Harris JM, Galbally I, Scheel HE, Bodeker G, et al. Long-term changes in tropospheric ozone. Atmos Environ 2006;40:3156-73.

Ordóñez C, Mathis H, Furger M, Henne S, Hüglin C, Staehelin J, et al. Changes of daily surface ozone maxima in Switzerland in al seasons from 1992 to 2002 and discussion of summer 2003. Atmos Chem Phys 2005;5:1187-203.

Prather M, Ehhalt D, Dentener F, Derwent R, Dlugokencky E, Holland E, et al. Atmospheric chemistry and greenhouse gases. Chapter 4 In: Houghton JT, Ding Y, Griggs Y, Noguer M, v.d.Linden PJ, Dai X, Maskell K, Johnson CA, editors. Climate change 2001, the scientific basis: contribution of working group I to the third assessment report of the intergovernmental panel on climate. Cambridge, United Kingdom: Cambridge University Press; 2001. p. 881 .

Rayner NA, Parker DE, Horton EB, Folland CK, Alexander LV, Rowell DP, et al. Global analyses of sea surface temperatures, sea ice, and nightmarine air temperature since the late nineteenth century. J Geophys Res 2003;108:4407. doi:10.1029/2002JD002670.

Roeckner E, Arpe K, Bengtsson L, Christoph M, Claussen M, Dümenil L, et al. The atmospheric general circulation model ECHAM4: model description and simulation of present-day climate. MPI-report, vol. 218. Hamburg, Germany. ISSN:0937-1060: Max-Planck-Institut für Meteorologie; 1996.

Roelofs G-J, Lelieveld J. Tropospheric ozone simulation with a chemistry-general circulation model: influence of higher hydrocarbon chemistry. J Geophys Res 2000;105:22 697-712.

Schnadt C, Dameris M, Ponater M, Hein R, Grewe V, Steil B. Interaction of atmospheric chemistry and climate and its impact on stratospheric ozone. Clim Dyn 2002;18:501-17.

Schnell RC, Liu SC, Oltmans SJ, Stone RS, Hofmann DJ, Dutton EG, et al. Decrease of summer tropospheric ozone concentrations in Antarctica. Nature 2001;351:726-9. doi:10.1038/351726a0.

Shine KP, Bourqui MS, Forster PM de F, Hare SHE, Langematz U, Braesicke P, et al. A comparison of model-predicted trends in stratospheric temperatures. Q J R Meteorol Soc 2003;129:1565-88.

Steil B, Dameris M, Brühl C, Crutzen PJ, Grewe V, Ponater M, et al. Development of a chemistry module for GCMs: first results of a multiannual integration. Ann Geophys 1998;16:205-28.

Steinbrecht W, Haßler B, Brühl C, Dameris M, Giorgetta M, Grewe V, et al. Interannual variation patterns of total ozone and temperature in observations and model simulations. Atmos Chem Phys 2006;6:349-74.

Stenke A, Grewe V. Simulation of stratospheric water vapor trends: impact on stratospheric ozone chemistry. Atmos Chem Physc 2005;5:1257-72.

Stevenson DS, Dentener FJ, Schultz MG, Ellingsen K, van Noije TPC, Wild O, Zeng G, et al. Multimodel ensemble simulations of present-day and near-future tropospheric ozone. J Geophys Res 2006;111:D08301. doi:10.1029/2005JD006338.

Stohl A, Bonasoni P, Cristofanelli P, Collins W, Feichter J, Frank A, et al Stratosphere troposphere exchange: a review, and what we have learned from STACCATO. J Geophys Res 2003;108. doi:10.1029/ 2002JD002 490.

Taalas P, Damski J, Kyrö E, Ginzburg M, Talamoni G. Effect of stratospheric ozone variations on UV radiation and on tropospheric ozone at high latitudes. J Geophys Res 1997;102(D1):1533-40. doi:10.1029/96JD02310.

Trenberth KE. The definition of El Niño. Bull Am Meteorol Soc 1997; 78:2771-7.

Vingarzan R. A review of surface ozone background levels and trends. Atmos Environ 2004;38:3431-42. 
Volz-Thomas A, Beekmann M, Derwent R, Law K, Lindskog A, Prévôt A, et al. Tropospheric ozone and its control. In: Midgley $\mathrm{P}$, et al, editors. Towards cleaner air for Europe - science, tools and application, Part 1: results from the EUROTRAC-2 Synthesis and Integration Project. Weikersheim: Margraf Verlag; 2003.

Wei M-Y. A new formulation of the exchange of mass and trace constituents between the stratosphere and troposphere. J Atmos Sci 1987;44:3079-86.
Wirth V, Egger J. Diagnosing extratropical synoptic-scale stratosphere- troposphere exchange: a case study. Q J R Meteorol Soc 1999;126:635-56.

WMO (World Meteorological Organization). Scientific assessment of ozone depletion: 2002. Global Ozone Research and Monitoring Project, Rep., vol. 47; 2003.

Ziemke JR, Chandra S. Seasonal and interannual variabilities in tropical tropospheric ozone. J Geophys Res 1999;104(D17):21425-42. doi:10.1029/1999JD900277. 